\title{
Formation of the innovation environment of enterprises in the real sector of the economy
}

\author{
Natalia Ershova $^{1, *}$, Nadezhda Sergeeva ${ }^{1}$, Yulia Kosova ${ }^{1}$, and Anastasia Fedotova ${ }^{2}$ \\ ${ }^{1}$ Russian State University of Justice, 69, Novocheremushkinskaya street, 117418, Moscow, Russia \\ ${ }^{2}$ Moscow Aviation Institute, Volokolamskoe highway, 4, 125993, Moscow, Russia
}

\begin{abstract}
The purpose of this study is to develop a methodology for the formation of an innovative business environment as an essential condition for the implementation of effective innovations that ensure the transition of the domestic economy to an innovative development path. The article explores modern approaches to the formation of an innovation environment and the definition of its place in the implementation of effective innovations, identifies the problems of implementing effective innovations and identifies potential solutions to them, analyzes the factors determining the formation of an innovation environment and ensures the implementation of effective innovations, identifies ways to improve the innovation climate in real sector of the economy. As a result of the research, a model for the formation of an innovation environment has been developed that ensures the implementation of effective innovations and assumes the creation of favorable conditions for the implementation of innovation activities.
\end{abstract}

\section{Introduction}

An important problem of innovative development of enterprises in the real sector of the economy is their acquisition of high-quality professional personnel in the conditions of population aging and growing competition with European and Asian markets for qualified production personnel. In addition to them, there are many other problems hampering the effective development of the sphere of processing industries of the domestic economy, related to tax legislation, demographic, climatic and geographical peculiarities of our country.

However, the key problem of effective innovation implementation is the lack of an enabling environment that stimulates the creation of innovations that provide competitive advantages and increases the investment attractiveness of the respective productions. Thus, the formation of an innovation environment as the most important condition for the implementation of effective innovations is an urgent scientific task of great economic importance [1].

In this study, the innovation environment is viewed as a set of socio-economic, organizational, legal, scientific, technological, political, and other objective and subjective

\footnotetext{
*Corresponding author: 5880972@mail.ru
} 
conditions that accompany the research processes that are being researched and are competitive in them, either stimulating or restraining [2].

\section{Materials and Methods}

Studies of modern approaches to the formation of an innovation environment have shown that the key ones are the following [3].

First, in the era of globalization of the economy, the informatization of society and the formation of innovative models of the socio-economic development of national economies, the innovation environment becomes a key source of innovation, ensuring:

- Accelerating and increasing the efficiency of the processes of creating innovations from the idea to the beginning of production, including at the expense of the ability of the innovation environment to generate synergy at the interfunctional and multi-institutional levels;

- increase in value added in the production of innovative products or with the use of innovations in the production process;

- increase in speed and expansion of the boundaries of diffusion of innovations in the distribution process.

In these conditions, when forming an innovation environment, it is necessary to ensure its organic inclusion in all phases of the reproduction cycle: "production-distributionexchange-consumption".

Secondly, taking into account the multiplicity of participants in the innovation environment (Fig. 1), as well as the multiple nature of the innovative environment implementation options in terms of the coverage of innovation process stages, it is necessary, as the innovation systems develop, to form an innovative environment, not simply on the basis of an integrated approach, where technical, economic, organizational, social, environmental, psychological and other aspects of innovation activity are taken into account [4].

Third, as the center of gravity of social and economic development shifts from traditional (routine) production and economic processes to innovative processes, the role of specialized innovation systems grows. Such systems are designed to ensure:

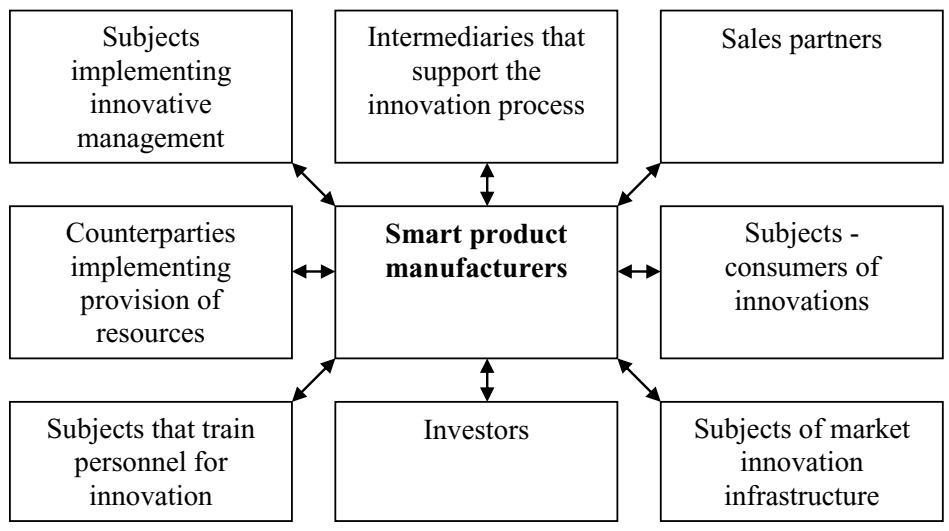

Fig. 1. Participants of the innovation environment.

- simplification of access to new technologies while creating innovations,

- distribution of high risks of innovation activities among participants in the innovation process,

- improve the efficiency of enterprises with innovative solutions to foreign markets, 
- the organization with initiators of innovations of joint carrying out of research and developmental works,

- ensuring the use of unique equipment through the creation of centers for collective use, as well as intellectual capital by creating data banks and knowledge bases,

- acceleration and increase of the effectiveness of the training processes in the management of innovation activity by concentrating high-level specialists and providing communication schemes for participants in innovation activities,

- lower transaction costs for operations

The composition of specialized organizations that form an innovative environment is presented in Table 1.

\section{Results}

The conducted studies show that the implementation of innovations in the real sector of the economy as a whole has a beneficial effect on the national economy (Fig. 2).

Table 1. The composition of specialized organizations that form an innovative environment.

\begin{tabular}{|c|c|c|}
\hline № & $\begin{array}{c}\text { Type of } \\
\text { organization }\end{array}$ & Content of activities \\
\hline 1 & $\begin{array}{l}\text { National } \\
\text { Research Centers }\end{array}$ & $\begin{array}{l}\text { The most significant institutions of science, in order to form the } \\
\text { technological base of the innovative economy, to ensure advanced } \\
\text { scientific and technological development and accelerated introduction of } \\
\text { scientific research into production, the full innovative cycle of research } \\
\text { and development }\end{array}$ \\
\hline 2 & $\begin{array}{l}\text { Institutes of the } \\
\text { Academy of } \\
\text { Sciences }\end{array}$ & $\begin{array}{l}\text { The highest scientific organizations of the Russian Federation, which } \\
\text { are the leading centers of fundamental research in the field of natural } \\
\text { and social sciences }\end{array}$ \\
\hline 3 & Scientific centers & $\begin{array}{l}\text { The center of scientific activity of the organization, region, country or } \\
\text { the world as a whole }\end{array}$ \\
\hline 4 & $\begin{array}{l}\text { Research } \\
\text { institutes }\end{array}$ & Laboratory for experiments and research \\
\hline 5 & Design offices & $\begin{array}{l}\text { An independent institution, specially created for the organization of } \\
\text { scientific research and development work }\end{array}$ \\
\hline 6 & $\begin{array}{l}\text { Design and } \\
\text { Technology } \\
\text { Institutes }\end{array}$ & $\begin{array}{l}\text { Special industry organizations that develop new technical means of } \\
\text { production, and innovative products for end users }\end{array}$ \\
\hline 7 & Technoparks & $\begin{array}{l}\text { Special organizations that prepare project and technological } \\
\text { documentation for the implementation of innovative production } \\
\text { activities }\end{array}$ \\
\hline 8 & $\begin{array}{l}\text { Business } \\
\text { incubators }\end{array}$ & $\begin{array}{l}\text { Property complexes in which scientific research institutions, } \\
\text { infrastructure facilities, including business and exhibition centers, } \\
\text { educational institutions, social facilities, etc., are united. }\end{array}$ \\
\hline 9 & $\begin{array}{l}\text { Special } \\
\text { economic zones } \\
\text { of innovative } \\
\text { type }\end{array}$ & $\begin{array}{l}\text { Organizations that support small, newly established enterprises that are } \\
\text { eager to start their entrepreneurial activities in conditions of a scarcity of } \\
\text { resources. }\end{array}$ \\
\hline 10 & Technopolis & $\begin{array}{l}\text { A limited area with a special legal status in relation to the rest of the } \\
\text { territory and preferential economic conditions for entrepreneurs, on } \\
\text { which scientific potential is concentrated, which opens up great } \\
\text { opportunities for the development of innovative business and production }\end{array}$ \\
\hline 11 & $\begin{array}{l}\text { Venture } \\
\text { companies }\end{array}$ & $\begin{array}{l}\text { The form of special economic zones created for activation, acceleration } \\
\text { of innovative processes, facilitating the rapid and effective application } \\
\text { of technical and technological innovations }\end{array}$ \\
\hline 12 & Endowment & Investment companies that work exclusively with innovative enterprises \\
\hline
\end{tabular}




\begin{tabular}{|c|l|l|}
\hline & Funds & $\begin{array}{l}\text { and projects (start-ups). They invest in enterprises with high or } \\
\text { relatively high risk in anticipation of extremely high profits from } \\
\text { innovation. }\end{array}$ \\
\hline 13 & $\begin{array}{l}\text { Consulting } \\
\text { Agencies }\end{array}$ & $\begin{array}{l}\text { Endowment funds that direct investment income from donor-generated } \\
\text { capital for their purposes, provided that donors have the right to clearly } \\
\text { indicate what the income received by the fund can be spent on. }\end{array}$ \\
\hline 14 & $\begin{array}{l}\text { Engineering } \\
\text { companies }\end{array}$ & $\begin{array}{l}\text { Companies providing professional services in the field of innovation, as } \\
\text { well as related issues in the field of taxation, intellectual property rights, } \\
\text { financial analysis, accounting, advertising, etc. }\end{array}$ \\
\hline 15 & $\begin{array}{l}\text { Centers for } \\
\text { independent } \\
\text { expertise }\end{array}$ & $\begin{array}{l}\text { Companies specializing in the provision of services in the field of } \\
\text { intellectual activity, in order to apply the achievements of science, } \\
\text { technology, the use of laws and natural resources to solve specific } \\
\text { problems }\end{array}$ \\
\hline 16 & $\begin{array}{l}\text { Innovative } \\
\text { exchanges }\end{array}$ & $\begin{array}{l}\text { Organizations engaged in carrying out independent expertise of } \\
\text { innovative developments (goods, works, services) and valuation of the } \\
\text { created intellectual property }\end{array}$ \\
\hline 17 & $\begin{array}{l}\text { Operating } \\
\text { companies }\end{array}$ & $\begin{array}{l}\text { Legal entities that ensure the functioning of an organized market of } \\
\text { innovative developments on a regular basis. }\end{array}$ \\
\hline 18 & $\begin{array}{l}\text { Innovative and } \\
\text { innovative firms }\end{array}$ & $\begin{array}{l}\text { Innovative firm, consciously going to great risk in the interests of profit } \\
\text { from the sale of not only innovative products and technologies, but also } \\
\text { from the implementation of innovative ideas }\end{array}$ \\
\hline 20 & $\begin{array}{l}\text { Technology } \\
\text { Transfer Centers }\end{array}$ & $\begin{array}{l}\text { Patron firms working at the stage of innovation between the innovation } \\
\text { idea and bringing innovative product development to the level of the } \\
\text { production model }\end{array}$ \\
\hline
\end{tabular}

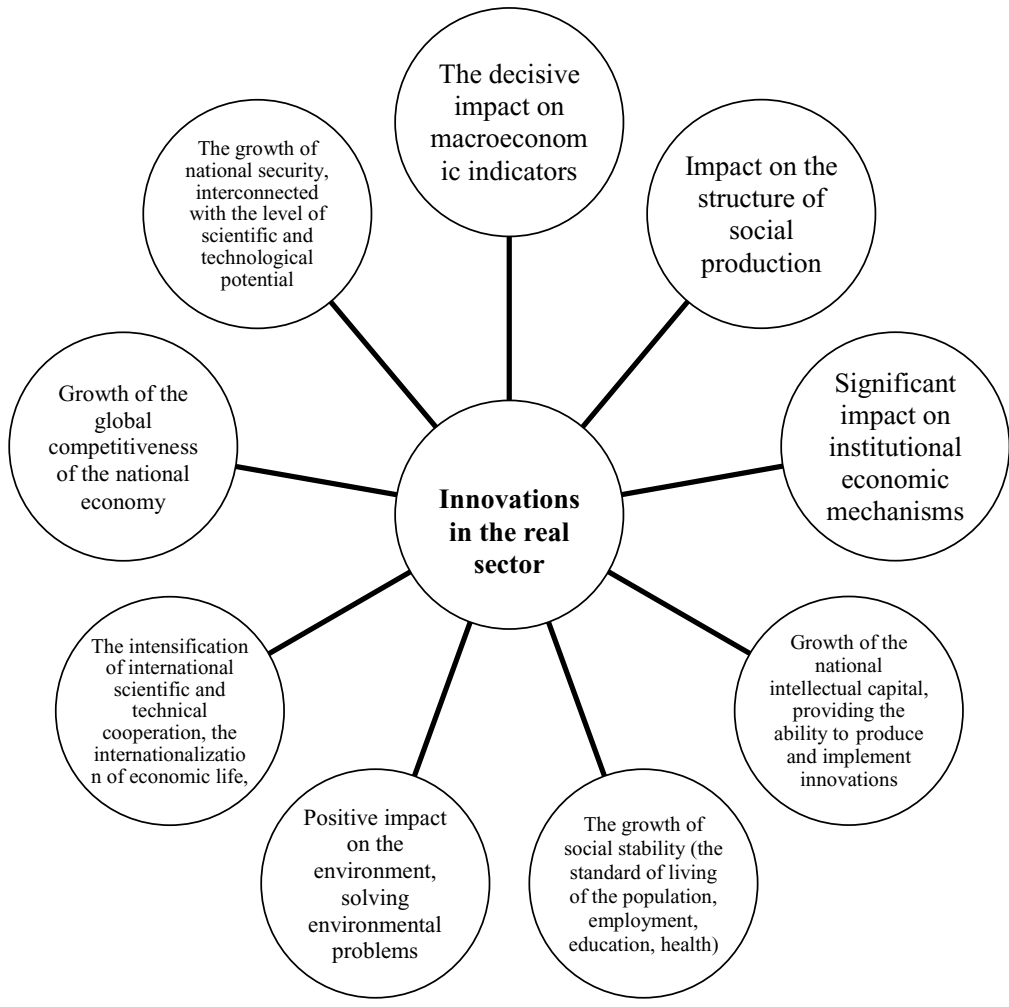

Fig. 2. Influence of innovations on the national economy. 
At the same time, conducted studies have shown that to implement effective innovation in the domestic economy there is a set of problems. Considering their systemic nature, the algorithm of the solution, presented in Fig. 3 .

Thus, the developed algorithm provides for the formation, based on the analysis of the features of the formation of an innovation environment, the formation of criteria for the effectiveness of the formation of an innovation environment and is aimed at improving approaches to the formation of an innovation environment for the implementation of effective innovations, including the formation of technology for effective management of innovation environment parameters [5].

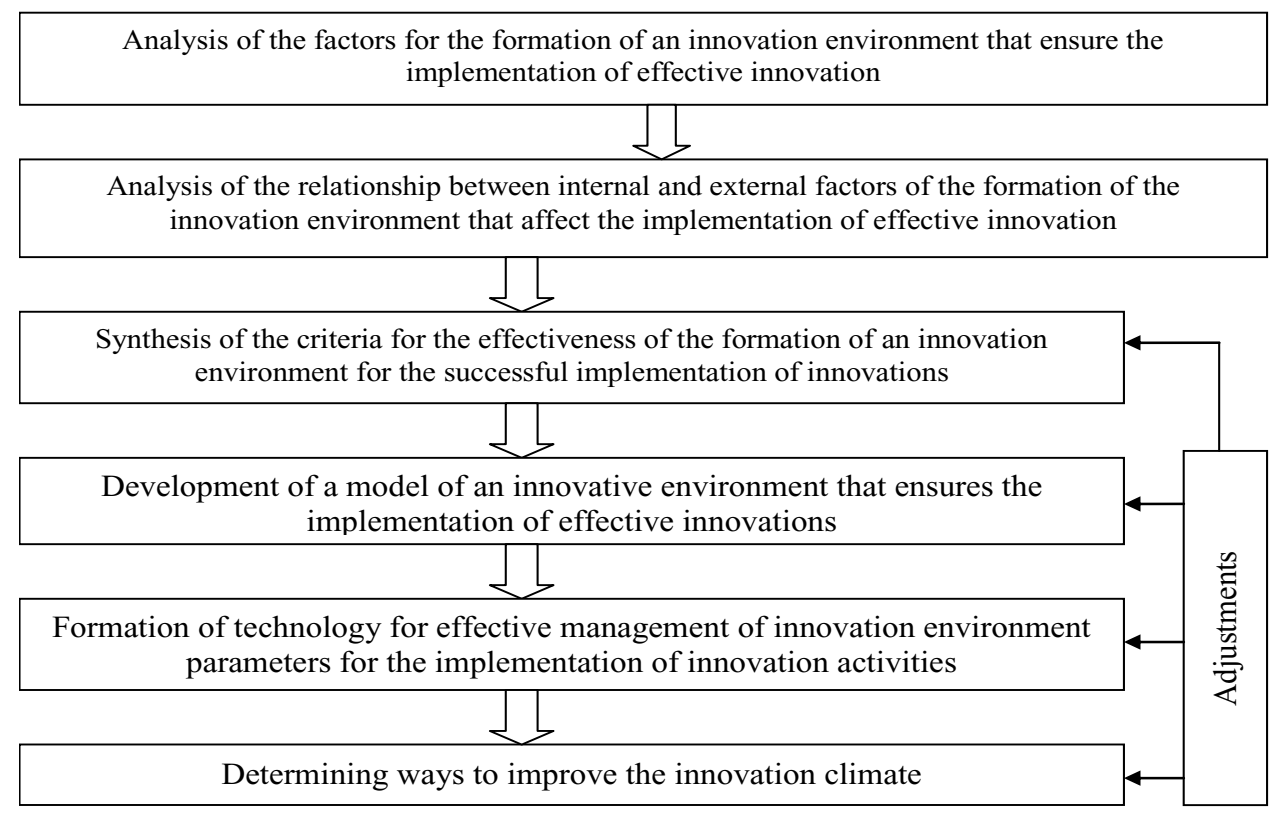

Fig. 3. Algorithm for solving the problems of implementing effective innovations.

The conducted researches in the field of the analysis of the factors of formation of the innovation environment have shown that among the external factors the greatest positive influence is exerted by the factor of scientific and technical progress, which provides in the advanced countries of the world $85-95 \%$ of GDP growth. The low level of the impact of scientific and technological progress on GDP growth in the Russian Federation is due exclusively to structural disproportions of the domestic economy, in which the share of all manufacturing industries in GDP does not exceed 3\%, while the share of the oil and gas complex exceeds $30 \%$ [6].

Among external factors, the relatively low level of financing of production innovation technologies, which constitute the active part of the fixed capital of enterprises, characterized by machinery and equipment, has the greatest negative impact on the formation of the innovation environment. In many respects this is also connected with the deformation of the ratio of GDP growth rates of the country as a whole (Tc), the growth rate of engineering (Tm) and the growth rates of high-tech industries (Tv), the vast majority of which is related to the sphere of manufacturing industries. While in the leading countries of the world the proportions of Tc: Tm: Tv are 1:2:4, in Russia the slower growth rates of manufacturing manufacturing industries in comparison with GDP growth remain one of the main constraints to the socioeconomic development of the country. Among external factors that negatively affect the formation of an innovative environment, we should also highlight the rise in prices for raw materials and energy [7]. 
Among the internal factors that positively influence the formation of the innovation environment, it is necessary to emphasize the development of intellectual capital, production resources of the providing production (including the introduction of equipment that implements new technologies) and financial capital directed to the development of the innovation environment [8].

Among the internal factors that negatively influence the formation of the innovation environment, there is a relatively low level of labor productivity in the domestic economy against the backdrop of the economies of the world's leading countries.

\section{Discussion}

The analysis of the factors of the formation of an innovation environment that ensures the implementation of effective innovations has made it possible to proceed to the identification of the interrelationships of internal and external factors affecting the formation of an innovative environment of the economic systems of the manufacturing industries [9].

Proceeding from the foregoing, in the work based on the theory of games using the Laplace criterion, technologies for the effective management of elements of the innovation environment for the implementation of innovative activities were substantiated [10, 11].

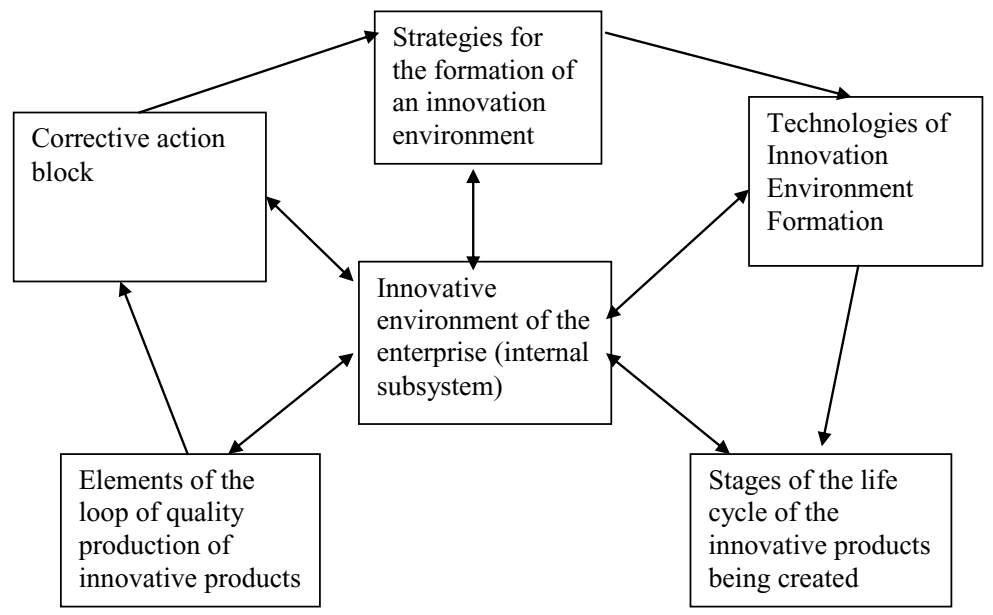

Fig. 4. Model of forming the internal subsystem of the innovation environment of enterprises in the real sector of the economy.

\section{Conclusion}

Taking into account the development of the model for the formation of an innovation environment that ensures the implementation of effective innovations and the justification of technologies for the effective management of innovation environment elements, innovative ways of improving the innovation sector in the economy have been identified in the real sector of the economy (including machine building, food production, woodworking, construction materials, glass production, textile and leather-shoe production, as well as agriculture economy), the simulation method showed that the increase in the efficiency of their activities as a result of the formation of innovative infrastructure can be an average of $14 \%$ over 1.5 years (modernization innovations) and about $49-64 \%$ for 4 years (innovations of a deep degree of radicalism). 


\section{References}

1. N.B. Safronova, A.R. Urubkov, A.S. Budakov, M. Myltsev, Serbian journal of management 11(2), 261-273 (2016) ISSN: 1452-4864 (print), $2217-7159$ (online)

2. A.M. Spryskov, D.S. Privorotsky, E.V. Privorotsky, N.A. Yashina, Proceedings of the Samara scientific center of RAS, 4-1 (2016)

3. R.S. Golov, V.V. Shilov, S.A. Silantiev, ASEE International Forum, Columbus, 20766 (2017)

4. A. Bril, O. Kalinina, O. Valebnikova, Lecture Notes in Computer Science 9870, 766775 (2016) doi:10.1007/978-3-319-46301-8_67

5. A.K. Orlov, I.Y. Chubarkina, MATEC Web of Conferences 106, 08015 (2017)

6. I.V. Ilin, A. Lepekhin, A.I. Levina, O.Yu. Iliashenko, Advances in Intelligent Systems and Computing 692, 1306-1314 (2018) doi:10.1007/978-3-319-70987-1_138

7. V. Gasilov, N. Anisimova, I. Provotorov, MATEC Web of Conferences 106, 08035 (2017) DOI: 10.1051/mateconf/ 201710608035

8. N. Verstina, E. Evseev, MATEC Web Conf. 106 (2017)

9. A.F. Sandvall, E.O. Ahlgren, T. Ekvall, Energy Strategy Reviews 18, 212-223 (2017)

10. S.V. Domnina, E.V. Savoskina, N.V. Shekhova, Procedia Engineering 153, 741-746 (2016)

11. S.A. Baronin, K.Y. Kulakov, Journal of Applied Economic Sciences 11(4), 698-708 (2016) 